\title{
空気圧で浮上する平板と支持構造の動的安定性 （支持構造の弾性が自励振動の発生条件に及ぼす影響）
}

\section{Dynamic stability of a floating plate and a support structure (Influence of elasticity of a support structure on occurrence conditions of the self-excited vibration)}

武田 真和 ${ }^{* 1}$ ，小澤 和典 ${ }^{* 2}$, 渡辺 昌宏 ${ }^{* 3}$

\author{
Masakazu TAKEDA $^{* 1}$, Kazunori OZAWA ${ }^{* 2}$ and Masahiro WATANABE*3

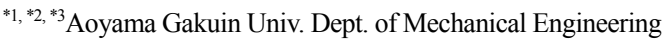 \\ 5-10-1 Fuchinobe, Chuo-ku, Sagamihara-shi, Kanagawa 252-5258, Japan
}

Received: 6 July 2018; Revised: 14 January 2019; Accepted: 17 March 2019

\begin{abstract}
This paper presents experiments and an analysis of the self-excited vibration of a floating plate and a support structure. The system in which a floating plate and a support structure vibrate, the elasticity of the support structure influences the stability of the system. Therefore, in this paper, the influence of the elasticity of the support structure on the vibration characteristics and occurrence conditions of the self-excited vibration is examined. In the analysis, the unsteady fluid force is calculated based on the basic equation of a two-dimensional leakage-flow between the plate and the support structure surface. The basic equation of leakage-flow considers the effect of air compressibility. Moreover, the equation of continuous air flow in the chamber includes the effect of air compressibility. The characteristic equation on the stability of the system is derived from the plate and the support structure motion coupled with the unsteady fluid force. The experiment consists of a floating plate and a support structure, where the vibration characteristics are examined. The influence of elasticity of the support structure on the vibration characteristics and occurrence conditions of the self-excited vibration are clarified comparing the analysis with experiments. Lastly, the local work done by the unsteady fluid force acting on the plate surface and the support structure surface is shown, and the instability mechanism is discussed.
\end{abstract}

Keywords : Self-excited vibration, Plate, Support structure, Unsteady fluid force, Instability mechanism

\section{1. はじめに}

製鉄所や液晶ディスプレイ用ガラス基板の製造工程などでは，チャンバ表面に設けたスリットや孔から供給さ れる空気の圧力により，鋼板やガラスなど（以下，平板と表記する）を浮上させて搬送を行う空気圧浮上搬送装 置が利用されている（下川他, 1994; 下川, 神山, 1996)。 また，火力発電所などでは，ベルトとベルト走行面（ト ラフ）の間に空気を流すことでベルトを浮上させて積載物（石炭やコークスなど）を搬送する空気浮上式コンベ アが利用されている（石原, 2007)。このような機械は，従来のローラーを用いた接触式搬送装置に比べて，平板 表面に傷が発生するリスクが小さいことから，多く利用されている．しかしながら，上述の空気圧浮上搬送装置 やコンベアに激しい自励振動が発生することが報告された（石原, 2007）。自励振動が発生すると，平板表面に傷 が発生するリスクが増大し，さらに騒音問題を引き起こすことがある。このため，自励振動の振動特性と発生条 件および励振メカニズムを解明することは，上述の機械の設計や自励振動抑止手法の確立のために重要である.

これまでに，大森ら（大森, 小林, 2000, 2001）は，空気浮上式コンベアを対象に安定性解析と実験を行い， べ

\footnotetext{
No.18-00289 [DOI:10.1299/transjsme.18-00289], J-STAGE Advance Publication date : 26 March, 2019

*1 正員, 青山学院大学大学院 理工学研究科（干252-5258 神奈川県相模原市中央区淵野辺 5-10-1）

*2 青山学院大学大学院 理工学研究科

*3 正員, 青山学院大学 理工学部 機械創造工学科

E-mail corresponding author: takeda@me.aoyama.ac.jp
} 
ルトの弾性変形と空気の寸き間流れが連成することで, 空気浮上したベルトに自励振動が発生することを示した. また，石原ら（石原, 2007; Ishihara, 2008; Ishihara and Eto, 2011）は，空気浮上式コンベアに発生する自励振動の 振動特性を調べ，自励振動はベルトとトラフの間を流れる空気の流れに起因した，すき間流れ励起振動であるこ とを示した. 寸き間流れ励起振動に関しては，稲田ら（稲田，葉山，1987）の研究報告があり，この研究では， 寸き間流れ励起振動の特性と発生条件，および励振メカニズムが示されている.

また，一般的な空気圧浮上搬送装置やコンベアは，配管から送られた空気を一度チャンバに蓄えてから供給す る構造となっているため, 著者ら（武田, 渡辺, 2016）は, 空気圧で浮上する平板について, チャンバ内の空気の 圧縮性を考慮した簡易解析モデルを構築し，解析と実験により自励振動の特性と発生条件を調べた．さらに，平 板（下部表面）に作用寸る流体力による仕事分布を調べることで，励振メカニズムを考察した，そして，石原ら

（石原, 2007; Ishihara, 2008; Ishihara and Eto, 2011）が報告した，すき間流れに起因する自励振動の発生機構だけで なく, チャンバ内の空気の圧縮性に起因して自励振動が発生することを示した. また, 著者ら (武田, 渡辺, 2018) は，チャンバ内の空気の圧縮性に加えて，すき間内空気の流体慣性と圧縮性を考慮した解析モデルを構築し，解 析と実験により，チャンバ体積と空気を供給するスリットの幅が自励振動の発生条件に及ぼす影響を明らかにし た.

しかしながら，空気圧浮上搬送装置やコンベアは，積荷の重量により支持構造が弾性変形する場合があり，支 持構造の弾性変形または弾性支持に起因した上下方向の激しい自励振動が発生することが示されている（石原, 2007). 上述の研究報告（武田，渡辺，2016, 2018）では，支持構造が固定された系を対象としたことから，支持構 造の弾性が系の動的安定性に及ぼす影響については調べられていない，特に，空気圧で浮上する平板と支持構造 が振動する系では，平板と支持構造の間の流体力を介して，平板と支持構造が連成して振動することから，支持 構造の弾性は系の安定性に大きな影響を及ぼすと考えられる。

そこで, 本研究では, 空気圧で浮上寸る平板と支持構造を対象に, 空気の圧縮性と流体慣性を考慮した解析モ デルを構築し, 空気圧で浮上する平板と支持構造に発生する自励振動の特性と発生条件を調べた. また, 実験を 行い, 解析と実験結果を比較することで, 支持構造の弾性が自励振動の特性と発生条件に及ぼす影響を明らかに した．特に本研究では，空気圧で浮上する平板と支持構造の安定性を支配する無次元数を新たに定義し，自励振 動が発生する条件を整理した，さらに，平板と支持構造の表面に作用する流体力の仕事分布を調べることで，自 励振動発生時のエネルギ収支を明らかにし，励振メカニズムを考察した。

\section{2. 動的安定性解析}

\section{$2 \cdot 1$ 解析モデルと動的安定性解析の流れ}

図 1 に解析モデルを示す．座標系は横方向に $X$ 軸, 奥行方向（図 1(b)の縦方向）に $Y$ 軸, 鉛直方向に $Z$ 軸を定 める. 空気圧浮上搬送装置やコンベアの支持構造には，弾性変形または弾性支持に起因した上下方向の自励振動 が発生する. 前報（武田, 渡辺, 2016, 2018）では, 空気圧で浮上する平板のみが振動する 1 自由度系を対象とし たため, 支持構造の弾性を考慮した系の動的安定性は明らかにされていない. そこで本研究では, ガラス基板の 搬送工程などで広く使用されている表面が平らなストレートモデルの支持構造と空気圧で浮上する平板からなる 2 自由度系を対象として, 自励振動の振動特性と発生条件を調べる. 平板は, 支持構造表面の中央に設けた 1 本 のスリットから供給される空気の圧力により浮上し，上下方向に並進振動すると仮定する．また，支持構造はバ ネとダンパにより支持され，平板と同様に上下方向に並進振動すると仮定する. なお，浮上する平板の $X$ 方向の 対称軸とスリットの位置は一致させて解析を行う。

平板下面と支持構造上面の間の寸き間における空気の流れは, 横方向（ $X$ 方向）と奥行方向（ $Y$ 方向）に流れ る二次元流れとし, 流路は $X$ 方向に $N_{X}$ 分割, $Y$ 方向に $N_{Y}$ 分割する. そして, 二次元すき間流れの基礎理論 $(\mathrm{Li}$ et al., 2002）を基に，流体慣性と空気の圧縮性を考慮することで，動的安定性解析を行う。また，前報（武田，渡 辺, 2016, 2018）より, 空気圧で浮上する平板は, チャンバ内の空気の圧縮性に起因して自励振動が発生するこ とが示されている. このため, 本研究で対象とする空気圧で浮上寸る平板と支持構造からなる 2 自由度系におい ても, チャンバ内の空気の圧縮性は, 系の安定性に影響を及ぼすと考えられる. そこで, 前報 (武田, 渡辺, 2016, 2018）と同様に，チャンバ内の空気の圧縮性を考慮して，動的安定性解析を行う. 
動的安定性解析の主な流れは，平板のみが振動する 1 自由度系を対象とした前報（武田, 渡辺, 2018）とほぼ同 様であるが, 本研究では, 平板に加えて支持構造の運動方程式を考慮して, 平板と支持構造の振動に関する 2 自 由度系の特性方程式を導出寸る. そして, 特性方程式の特性根であるラプラス変数 $s$ の值により系の安定性を判 別し, 自励振動が発生する条件を求める. 詳細な安定性解析の流れは, 前報（武田, 渡辺, 2018）を参照のこと.

なお，空気圧浮上搬送装置において，平板は搬送時の張力および減衰に起因するバネ特性とダンパ特性を有す るために, 前報（武田, 渡辺, 2018）では, 平板にバネとダンパを付加した. 一方, 本研究では, 支持構造の弾性 変形または弾性支持に起因した上下方向の自励振動の特性と発生条件を調べるために，支持構造にバネとダンパ を付加する．このとき，平板にはバネとダンパを付加しない系を対象とすることで，モデルを簡易化して解析を 行う。そして，支持構造の弾性が自励振動の特性と発生条件に及ぼす影響を明らかにする，平板にバネとダンパ を付加した系に発生する自励振動の特性と発生条件は，前報（武田, 渡辺, 2018）を参照のこと.

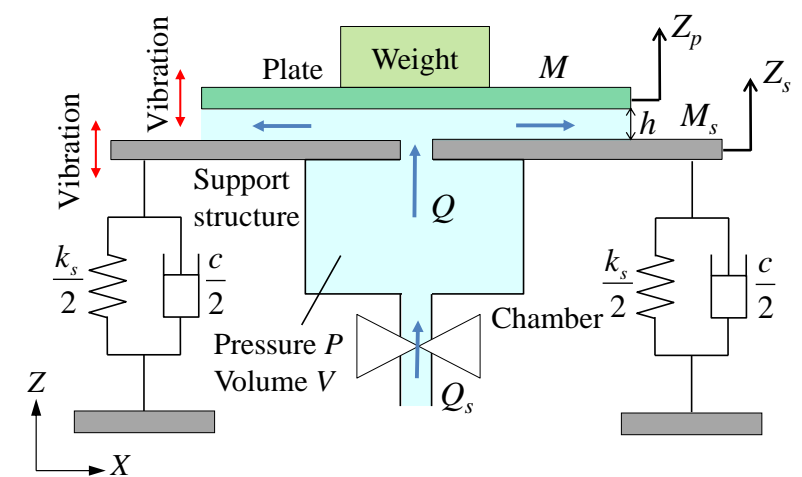

(a) Cross section of the structure

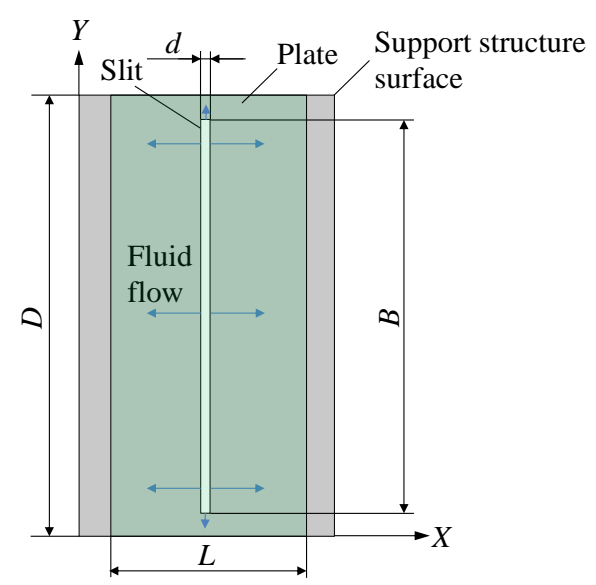

(b) Support structure and plate surface

Fig. 1 Schematic illustrations of the analytical model. The plate floats due to the pressure of the air supplied from the slit at the center of the upper surface of the support structure. The plate and the support structure vibrate to vertical direction.

\section{$2 \cdot 2$ 平板と支持構造の運動方程式}

平板の変位, 平板質量 (平板と積載物の合計質量) をそれぞれ $Z_{p}, M$ とし, 重力加速度を $g$ とすると, 平板 の運動方程式は, 以下のように得られる。

$$
M \ddot{Z}_{p}+M g=A_{d} \sum_{j=1}^{N_{X}} \sum_{k=1}^{N_{Y}} P_{g}(j, k)
$$

上式において，右辺は平板に作用する流体力を示している． $P_{g}$ は，平板下面と支持構造上面の間のすき間にお ける空気の圧力を表し, 記号 $j$ と $k$ は節点番号, $N_{X}$ と $N_{Y}$ はそれぞれ $X$ 方向と $Y$ 方向の流路分割数を表す.また, $A_{d}$ は離散化した流路の格子面積を表し, 以下のように与えられる.

$$
A_{d}=\ell_{x} L \ell_{y} D
$$

式中の $L$ は平板の幅， $D$ は平板の長さを表す．また， $\ell_{x}, \ell_{y}$ は，それぞれ $X$ 方向と $Y$ 方向の無次元化した流路 格子長さを表す．格子モデルの詳細は，前報（武田, 渡辺, 2018）を参照.

一方，支持構造の変位，支持構造の質量，減衰係数，バネ定数をそれぞれ $Z_{s}, M_{s}, c, k_{s}$ とすると，支持構 造の運動方程式は，以下のように得られる.

$$
M_{s} \ddot{Z}_{s}+c \dot{Z}_{s}+k_{s} Z_{s}+M_{s} g=-A_{d} \sum_{j=1}^{N_{X}} \sum_{k=1}^{N_{Y}} P_{g}(j, k)
$$


また，支持構造に対する平板の相対変位（平板の浮上変位） $h$ は，以下のように得られる.

$$
h=Z_{p}-Z_{s}
$$

\section{$2 \cdot 3$ 流体系の基礎式}

流体系の基礎式は，前報（武田, 渡辺, 2018）と同様とする. 平板下面と支持構造上面の間のすき間における空 気の圧縮性を考慮した連続の式と, 寸き間内の空気密度 $\rho$ と圧力 $P_{g}$ の関係式は, 以下のように与えられる.

$$
\begin{aligned}
& \frac{\partial \rho Q_{X}}{\partial X}+\frac{\partial \rho Q_{Y}}{\partial Y}+\rho \frac{\partial h}{\partial t}=0 \\
& \rho=P_{g} \frac{\rho_{a}}{P_{a}}
\end{aligned}
$$

また，すき間における $X$ 方向と $Y$ 方向の空気流れの基礎式は，以下のように与えられる.

$$
\begin{aligned}
& \frac{1}{\rho} \frac{\partial P_{g}}{\partial X}=-\frac{1}{h}\left\{\frac{\partial Q_{X}}{\partial t}+\frac{\partial}{\partial X}\left(\frac{Q_{X}^{2}}{h}\right)+\frac{\partial}{\partial Y}\left(\frac{Q_{X} Q_{Y}}{h}\right)+\frac{12 v Q_{X}}{h^{2}}\right\} \\
& \frac{1}{\rho} \frac{\partial P_{g}}{\partial Y}=-\frac{1}{h}\left\{\frac{\partial Q_{Y}}{\partial t}+\frac{\partial}{\partial Y}\left(\frac{Q_{Y}^{2}}{h}\right)+\frac{\partial}{\partial X}\left(\frac{Q_{X} Q_{Y}}{h}\right)+\frac{12 v Q_{Y}}{h^{2}}\right\}
\end{aligned}
$$

記号の詳細と式の仮定については，末尾の記号表と前報（武田，渡辺,2018）を参照.

また, チャンバ内の空気の体積弾性係数を $K_{e}$ とすると, 空気の圧縮性を考慮したチャンバ内の空気流れの連続 の式は，以下のように得られる.

$$
\frac{V}{K_{e}} \frac{d P}{d t}=Q_{s}-Q
$$

図 2 に，支持構造表面に設けたスリット部の概略図を示す．図 2 の赤線部では，スリット入口の絞り（流体抵 抗）に起因した圧力降下が生じる.このとき，チャンバ内部とスリット直上の差圧 $\left(P-P_{s}\right)$ およびスリットを 通過する空気の流量 $Q$ の関係式は，以下のように与えられる.

$$
Q=C_{d s} A_{s} \sqrt{2\left(P-P_{s}\right) / \rho_{s}}
$$

式中の $\rho_{s}$ はスリット部の空気密度を， $C_{d s}$ はスリット部の流量係数を表す．また， $A_{s}$ は，スリット入口部（絞り 部）の面積を表し，スリットの長さ $B$ とスリットの幅 $d$ を用いて， $A_{s}=B \cdot d$ で与えられる.

一方，図 2 の黄線部では，すき間入口の絞り（流体抵抗）に起因した圧力降下が生じる．1 本のスリットから 空気が供給される場合，スリットから供給される空気の流れは，スリット端部を除き，スリット長手方向にほぼ 一様な分布となる．このため，本研究では，スリットから供給される空気は，すき間内に一様に供給されると仮 定する. このとき，スリット直上とすき間入口の差圧 $\left(P_{s}-P_{g 0}\right)$ およびすき間入口を通過する空気の流量 $Q$ の関 係式は，すき間入口の流量係数 $C_{d g}$ を用いて，以下のように与えられる.

$$
Q=C_{d g} A_{g} \sqrt{2\left(P_{s}-P_{g 0}\right) / \rho_{s}}
$$

式中の $A_{g}$ は, すき間入口部（絞り部）の面積を表し, スリットの長さ $B$, スリットの幅 $d$, すき間幅 $h$ を用いて, $A_{g}=2(B+d) h$ で与えられる. 


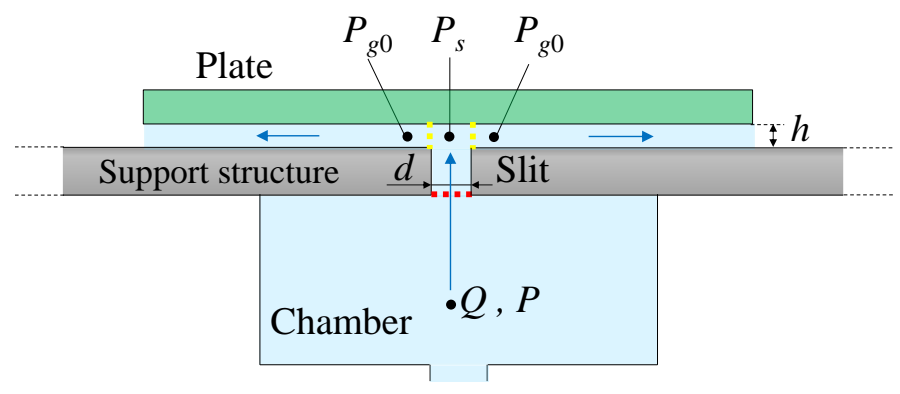

Fig. 2 Schematic illustration of air flowing through the slit provided on the support structure surface. The pressure drop occurs in the red line section (the slit entrance) and the yellow line section (the gap entrance).

\section{$2 \cdot 4$ 定常方程式と非定常方程式}

平板と支持構造の運動方程式および流体系の基礎式に含まれる変数を，摂動法を用いて定常項と非定常項に分 離すると, 定常方程式は以下のように得られる. 式中の記号 - は定常成分であることを表す. 寸き間内の空気 流れの連続の式（式 (5)）と $X$ 方向と $Y$ 方向の空気流れの基礎式（式（7），(8)）は，二次元すき間流れの基礎 理論 (Li et al., 2002) に基づき, 離散化して式を整理した. 式の導出仮定と記号の詳細は, 前報 (武田, 渡辺, 2018) と末尾の記号表を参照.

$$
\begin{aligned}
& \bar{P}_{g}(j+1, k)=\bar{P}_{g}(j, k)-\frac{12 \rho_{x}(j, k) L \ell_{x} v \bar{Q}_{x}(j, k)}{\bar{h}^{3}} \\
& \bar{P}_{g}(j, k+1)=\bar{P}_{g}(j, k)-\frac{12 \rho_{y}(j, k) D \ell_{y} v \bar{Q}_{y}(j, k)}{\bar{h}^{3}} \\
& \bar{P}_{g}(j, k)=\left[b_{1}\left\{\bar{P}_{g}(j+1, k)+\bar{P}_{g}(j-1, k)\right\}+b_{2}\left\{\bar{P}_{g}(j, k+1)+\bar{P}_{g}(j, k-1)\right\}\right] / A_{p} \\
& b_{1}=\ell_{y}^{2} D^{2}, \quad b_{2}=\ell_{x}^{2} L^{2}, \quad A_{P}=2\left(\ell_{y}^{2} D^{2}+\ell_{x}^{2} L^{2}\right) \\
& \bar{Q}_{=}=Q_{s} \\
& \bar{P}_{s}=\bar{P}-\frac{\rho_{s} \bar{Q}^{2}}{2 C_{d s}^{2} A_{s}^{2}} \\
& \bar{P}_{g 0}=\bar{P}_{s}-\frac{\rho_{s} \bar{Q}^{2}}{2 C_{d g}^{2} A_{g}^{2}} \\
& M g=A_{d} \sum_{j=1}^{N_{X}} \sum_{k=1}^{N_{Y}} \bar{P}_{g}(j, k) \\
& \bar{h}_{s} \bar{Z}_{s}+M_{s} g=-A_{d} \sum_{j=1}^{N_{X}} \sum_{k=1}^{N_{Y}} \bar{P}_{g}(j, k) \\
& \bar{Z}_{p}-\bar{Z}_{s}
\end{aligned}
$$


一方, 非定常方程式は，以下のように得られる. 式中の $s$ は，ラプラス変数を表す．また，記号 $\Delta$ は非定常成 分 (非定常項) であることを表し，記号 〜 はラプラス変換した変数であることを表す. 以下の式では，振動に関 する非定常項は小さいとして，これらの項に関して非定常方程式を線形化した.

$$
\begin{aligned}
& \Delta \tilde{P}_{g}(j+1, k)=\Delta \tilde{P}_{g}(j, k)+\frac{\rho_{x}(j, k) L \ell_{x}}{\bar{h}}\left\{-s \cdot \Delta \tilde{Q}_{x}(j, k)+\frac{\bar{Q}_{x}(j, k)}{\bar{h}} s \cdot \Delta \tilde{h}-\frac{12 v \Delta \tilde{Q}_{x}(j, k)}{\bar{h}^{2}}+\frac{36 v \bar{Q}_{x}(j, k) \Delta \tilde{h}}{\bar{h}^{3}}\right\} \\
& \Delta \tilde{P}_{g}(j, k+1)=\Delta \tilde{P}_{g}(j, k)+\frac{\rho_{y}(j, k) D \ell_{y}}{\bar{h}}\left\{-s \cdot \Delta \tilde{Q}_{y}(j, k)+\frac{\bar{Q}_{y}(j, k)}{\bar{h}} s \cdot \Delta \tilde{h}-\frac{12 v \Delta \tilde{Q}_{y}(j, k)}{\bar{h}^{2}}+\frac{36 v \bar{Q}_{y}(j, k) \Delta \tilde{h}}{\bar{h}^{3}}\right\} \\
& \Delta \tilde{P}_{g}(j, k)=\left[b_{1}\left\{\Delta \tilde{P}_{g}(j+1, k)+\Delta \tilde{P}_{g}(j-1, k)\right\}+b_{2}\left\{\Delta \tilde{P}_{g}(j, k+1)+\Delta \tilde{P}_{g}(j, k-1)\right\}\right] / A_{p} \\
& -\frac{b_{1} b_{2}}{A_{p}} \frac{\rho(j, k)}{\bar{h}^{3}}\left(\bar{h}^{2} s+12 v\right) s \Delta \tilde{h} \\
& \frac{V}{K_{e}} \Delta \tilde{P} \cdot s=-\Delta \tilde{Q} \\
& \Delta \tilde{P}_{s}=\Delta \tilde{P}-\frac{\rho_{s} \bar{Q}}{C_{d s}^{2} A_{s}^{2}} \Delta \tilde{Q} \\
& \Delta \tilde{P}_{g 0}=\Delta \tilde{P}_{s}-\frac{\rho_{s} \bar{Q}}{C_{d g}^{2} A_{g}^{2}}\left(\Delta \tilde{Q}-\frac{\bar{Q}}{\bar{h}} \Delta \tilde{h}\right) \\
& M s^{2} \Delta \tilde{Z}_{p}=A_{d} \sum_{j=1}^{N_{X}} \sum_{k=1}^{N_{Y}} \Delta \tilde{P}_{g}(j, k) \\
& \left(M_{s} s^{2}+c s+k_{s}\right) \Delta \tilde{Z}_{s}=-A_{d} \sum_{j=1}^{N_{X}} \sum_{k=1}^{N_{Y}} \Delta \tilde{P}_{g}(j, k) \\
& \Delta \tilde{h}=\Delta \tilde{Z}_{p}-\Delta \tilde{Z}_{s}
\end{aligned}
$$

\section{$2 \cdot 5$ 安定判別}

非定常方程式（式（22）～（30））をラプラス変数 $s$ に関して整理すると, 以下の 6 次の特性方程式が得られ る. 式中の係数 $a_{i}$ は, 定常方程式 (式 (12) ～(21) ) を解くことで得られる定常項, 空気の物性值, 平板質量, 支持構造質量, 減衰係数, バネ定数および流路寸法からなる係数を表す.

$$
a_{6} s^{6}+a_{5} s^{5}+a_{4} s^{4}+a_{3} s^{3}+a_{2} s^{2}+a_{1} s+a_{0}=0
$$

本研究では, チャンバに供給する空気流量 $Q_{s}$ を変化させて, 式 (31) を満足する特性根 $s$ の值を求めることで, 系の安定判別を行う。得られる特性根 $s$ のうち 1 つでも実数部が正（Re $[s]>0 ）$ の根があれば, 系は不安定とな り，このとき $\operatorname{Im}[s] \neq 0$ の場合には，平板と支持構造が連成して振動する自励振動が発生する.

\section{$2 \cdot 6$ 平板と支持構造の振動モード}

平板と支持構造の振動モードを調べるために, 非定常方程式を整理する. 平板と支持構造に作用する非定常流 体力を $\Delta \tilde{F}(s)$ とすると，平板と支持構造の運動方程式（非定常方程式）は，以下のように表すことができる. 


$$
\begin{aligned}
& M s^{2} \Delta \tilde{Z}_{p}(s)=\Delta \tilde{F}(s) \\
& \left(M_{s} s^{2}+c s+k_{s}\right) \Delta \tilde{Z}_{s}(s)=-\Delta \tilde{F}(s)
\end{aligned}
$$

式 (32)，（33）を平板の振動変位 $\Delta \tilde{Z}_{p}(s)$ と支持構造の振動変位 $\Delta \tilde{Z}_{s}(s)$ に関して整理すると，以下の式が得ら れる。

$$
\frac{\Delta \tilde{Z}_{p}(s)}{\Delta \tilde{Z}_{s}(s)}=-\frac{M_{s} s^{2}+c s+k_{s}}{M s^{2}}
$$

式（34）に，特性方程式（式（31））を解くことで得られる特性根 $s$ の值を代入することで，支持構造の振動変 位に対する平板振動変位の位相差を求めた.

\section{$2 \cdot 7$ 流体力による仕事}

平板と支持構造に発生する自励振動の励振メカニズムを考察するために, 自励振動の励振に関与している流体 力が作用する領域を調べる. 平板と支持構造表面の各節点 $(j, k)$ に作用する流体力 $F_{j, k}$ による 1 周期当りの局所的 仕事 $E_{\text {local }}^{(j, k)}$ （仕事分布）は，以下の式（35）で与えられる. 式中の $\left|F_{j, k}\right|$ は流体力の振幅を表し， $|h|$ は平板の支持 構造に対する相対振動変位の振幅を表す.また $\phi_{j, k}$ は, 相対振動変位に対する流体力の位相差を表す. 以下の安 定性解析では，自励振動が発生する臨界流量 $\left(Q_{s}=Q_{s-c r}\right)$ における仕事分布を計算して示した.

$$
E_{l o c a l}^{(j, k)}=\oint F_{j, k} \cdot \dot{h} d t=\left|F_{j, k}\right| \cdot|h| \cdot \pi \sin \phi_{j, k}
$$

\section{$2 \cdot 8$ 支配無次元数}

本研究では，空気圧で浮上する平板と支持構造の安定性を支配する無次元数を新たに定義し，自励振動が発生 する条件を整理する. 無次元数を定義するにあたり, 代表長さを平板の幅 $L$, 代表時間を $T_{s}=\sqrt{M / K_{e 0} L}$ に設定 する. ここで， $K_{e 0}$ は大気圧中の空気の体積弾性係数を表す. そして, 空気圧で浮上する平板と支持構造の安定 性を支配する無次元数を以下のように定義する. ここで, $\mu$ は支持構造に対する平板の質量比, $q_{s}$ は無次元流量, $k_{s}^{*}$ は無次元バネ定数を表す.

$$
\mu=\frac{M}{M_{s}}, \quad q_{s}=Q_{s} \frac{T_{s}}{L^{3}}, \quad k_{s}^{*}=\frac{k_{s}}{K_{e 0} L}
$$

\section{$2 \cdot 9$ 解析パラメータ}

解析に用いた主なパラメータを表 1 に示寸. 支持構造の構造減衰比 $\zeta$ の值は，(後述する実験装置の) 支持構造 の打撃試験より実験的に求めた值 $(\zeta=0.05)$ である. 本研究の動的安定性解析では, 特記する場合を除き, $\zeta=0.05$ として計算を行うが, 支持構造の減衰要素は系の動的安定性に重要な因子になると考えられる. そこで，支持構 造の減衰比を変化させた場合の動的安定性解析も行う.

また，スリット部の流量係数 $C_{d s}$ とすき間入口の流量係数 $C_{d g}$ の值は，前報（武田，渡辺，2018）と同様に，す き間入口の前後とスリットの前後で圧力を測定し，その圧力差から実験的に求めた值を用いた．平板下面と支持 構造上面間のすき間における流路の分割数は, $X$ 方向分割数 $N_{X}=100, Y$ 方向分割数 $N_{Y}=100$ で計算を行った. 設定した分割数は，計算結果がほぼ一定值に収束するまで増加させて決定した.

計算は，チャンバに供給する空気流量 $Q_{s}$ と平板質量 $M$ を変化させることで，平板と支持構造に自励振動が発 生する臨界条件を求めた. そして, 式（36）に示した 3 つの無次元数を用いて結果を整理した. 
Table 1 Parameters used in the calculation.

\begin{tabular}{lcc}
\hline \hline Spring constant $k_{s}$ & {$[\mathrm{~N} / \mathrm{m}]$} & $10.5 \times 10^{4}, 50.2 \times 10^{4}$ \\
Support structure mass $M_{s}$ & {$[\mathrm{~kg}]$} & 26.5 \\
Slit width $d$ & {$[\mathrm{~mm}]$} & 3.0 \\
Slit length $B$ & {$[\mathrm{~mm}]$} & 620 \\
Plate width $L$ & {$[\mathrm{~mm}]$} & 180 \\
Plate length $D$ & {$[\mathrm{~mm}]$} & 700 \\
Chamber volume $V$ & {$\left[\mathrm{~m}^{3}\right]$} & $3.0 \times 10^{-3}$ \\
Fluid density $\rho_{a}$ & {$\left[\mathrm{~kg} / \mathrm{m}^{3}\right]$} & 1.2 \\
Kinematic viscosity $v$ & {$\left[\mathrm{~m}^{2} / \mathrm{s}\right]$} & $1.5 \times 10^{-5}$ \\
Damping ratio $\zeta$ & & 0.05 \\
Flow coefficient of slit $C_{d s}$ & & 0.85 \\
Flow coefficient of gap entrance $C_{d g}$ & & 0.85 \\
Gravity acceleration $g$ & {$\left[\mathrm{~m} / \mathrm{s}^{2}\right]$} & 9.81 \\
\hline
\end{tabular}

\section{3. 実験装置および実験方法}

図 3 と図 4 に実験装置の概略図と写真を示す. また, 図 5 に平板の写真を, 図 6 に支持構造表面の写真を示す. 実験の主なパラメータを表 2 に示す。支持構造は，コイルバネとリニアベアリングにより上下方向に動くように 支持されている，ブロワから送られた空気はチャンバへ蓄えられた後，支持構造表面の中央に設けた 1 本のスリ ットから流出する. そして，流出する（平板下面と支持構造上面間のすき間に供給される）空気の圧力により， 平板は浮上する.このとき, 支持構造表面に設けたストッパーによって, 平板の $X$ 方向の対称軸がスリットの位 置と一致するようにした（図 3 参照）。なお，このストッパーは十分に小さいため，平板下部の空気流れに対す る影響は小さい.

チャンバに供給される空気の流量 $Q_{s}$ は，配管に設置した流量計で計測した。また，平板の上に載せた重りの大 きさを調整することで, 質量 $M$ （平板と積載荷重の合計質量）を変化させた，平板および支持構造の変位は，平 板上部の右端部と左端部の 2 箇所，および支持構造下部に設置したレーザ変位計を用いて測定した。また，平板 の支持構造に対する相対変位 $h$ は，平板上に設置した渦電流式ギャップセンサを用いて測定した.

さらに本実験では，自励振動発生時における相対振動変位と，平板下面と支持構造上面の間の寸き間内空気の 圧力変動を同時測定することで，流体力による局所的仕事を調べて，励振メカニズムを考察した．すき間内の空 気の圧力変動は, 圧力センサと, 平板表面上の $X$ 方向と $Y$ 方向多点の位置に設けた圧力測定孔（図 5 参照）をチ ユーブで接続することにより測定した. そして, 位相平均法（武田, 渡辺, 2016）を用いて, 最大で計 80 点の位 置で圧力変動を測定した. 流体力による 1 周期当たりの局所的仕事 $E_{\text {local }}$ （流体力の仕事分布）は，圧力変動の振 幅 $\left|P_{i}\right|$, 相対振動変位の振幅 $|h|$, および（相対振動変位に対する圧力変動の）位相差 $\phi_{i}$ を用いて以下のように求 まる.

$$
E_{\text {local }}=\oint P_{i} \dot{h} d t=\left|P_{i}\right| \cdot|h| \cdot \pi \sin \phi_{i} \quad\left[\mathrm{~J} / \mathrm{m}^{2}\right]
$$

式中の $i$ は平板表面上の圧力測定点の番号を表す. 流体力による局所的仕事が正の領域を調べることで，平板 と支持構造に発生する自励振動を励起する圧力変動が，すき間内のどこで発生しているのか（励振エネルギが流 入する場所）を明らかにすることができる. 


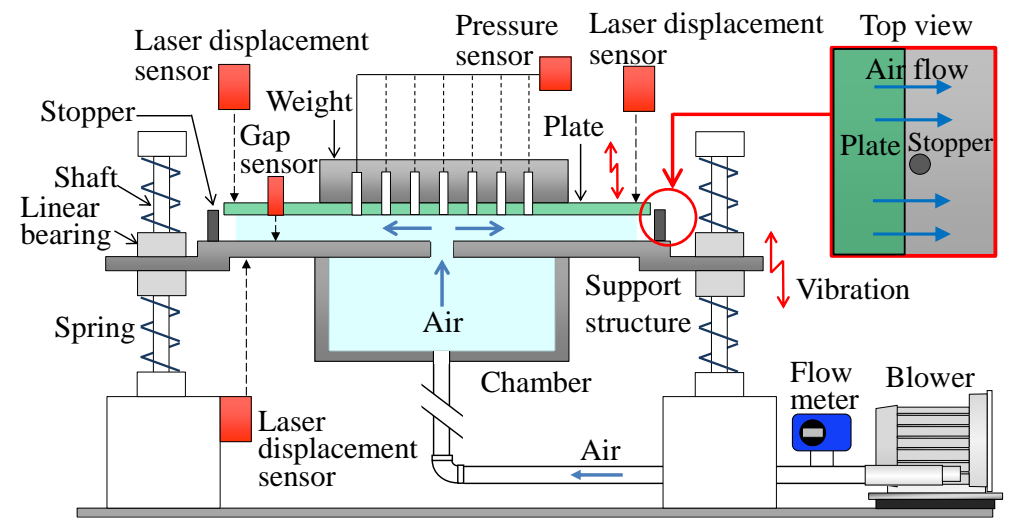

Fig. 3 Schematic illustration of the experimental apparatus. In the experiments, air sent from the blower is firstly stored in the chamber. Then, air flow out from the slit on the support structure surface. The plate floats by the pressure of the air. Also, the self-excited vibration occurs in the plate and the support structure depending on conditions.

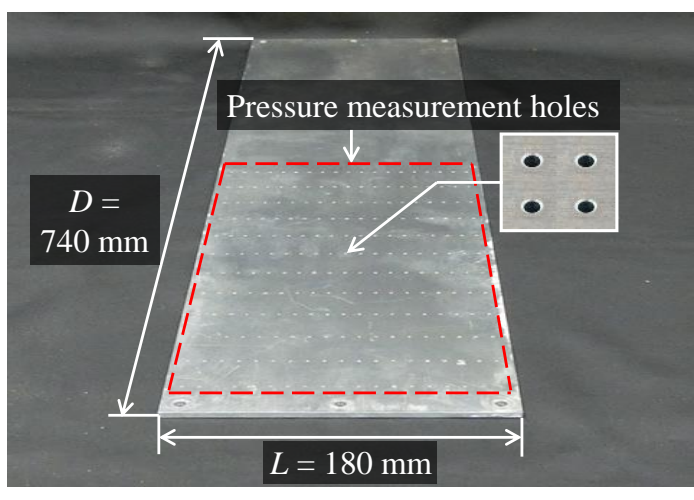

Fig. 5 Photograph of the plate surface. The plate has pressure measurement holes.

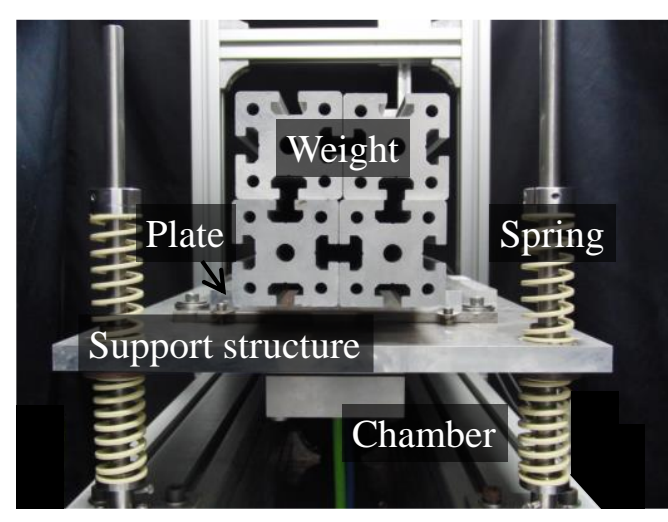

Fig. 4 Photograph of the experimental apparatus. The weight is loaded on the top of the plate. The chamber is provided at the bottom of the support structure.

Table 2 Parameters of the experiments.

\begin{tabular}{lcc}
\hline \hline Inflow rate $Q_{s}$ & {$\left[\mathrm{~m}^{3} / \mathrm{min}\right]$} & $0.04 \sim 0.3$ \\
Plate mass $M$ & {$[\mathrm{~kg}]$} & $6.0 \sim 44.4$ \\
Support structure mass $M_{s}$ & {$[\mathrm{~kg}]$} & 26.5 \\
Spring constant $k_{s}$ & {$[\mathrm{~N} / \mathrm{m}]$} & $10.5 \times 10^{4}, 50.2 \times 10^{4}$ \\
Slit width $d$ & {$[\mathrm{~mm}]$} & 3.0 \\
Slit length $B$ & {$[\mathrm{~mm}]$} & 620 \\
Plate width $L$ & {$[\mathrm{~mm}]$} & 180 \\
Support structure surface width $L_{s}$ & {$[\mathrm{~mm}]$} & 230 \\
Plate length $D$ & {$[\mathrm{~mm}]$} & 740 \\
Support structure surface length $D_{s}$ & {$[\mathrm{~mm}]$} & 700 \\
Chamber volume $V$ & {$\left[\mathrm{~m}^{3}\right]$} & $3.0 \times 10^{-3}$ \\
\hline
\end{tabular}




\section{4. 解析結果と実験結果および考察}

\section{$4 \cdot 1$ 実験で得られた時刻歴波形}

図 7 に，実験によって得られた平板と支持構造に発生する自励振動の時刻歴波形を示す。ここでは，代表的な 結果として, 空気流量 $Q_{s}=0.30 \mathrm{~m}^{3} / \mathrm{min}$, バネ定数 $k_{s}=50.2 \times 10^{4} \mathrm{~N} / \mathrm{m}$, 平板質量 $M=40.4 \mathrm{~kg}$ (図 7(a)) と $M=11.6 \mathrm{~kg}$

(図 7(b)）の結果を示す.これらの結果は, 振動中心の位置を変位 0 として表示している. なお, 平板の振動中 心である定常的な浮上変位 $\bar{h}$ の值は, 図中に数值で示している.これらの図に示した平板の振動变位については, 平板上部の右端部と左端部に設置したレーザ変位計（図 3 参照）により得られた，2つの時刻歴波形を示してい る.

図より, 平板と支持構造が連成して振動する系では, 平板と支持構造がほぼ同位相で振動する同位相モード (図 7(a)）と，ほぼ逆位相で振動する逆位相モード（図 7(b)）の自励振動が発生することがわかる.この同位相モード と逆位相モードの自励振動は, どちらの振動モードにおいても, 支持構造の振幅より平板の振幅の方が大きいこ とがわかる。ささらに，逆位相モードに対して同位相モードの方が，平板と支持構造の振幅が大きい.

また, どちらの振動モードにおいても, 平板右端部と左端部の振動変位は, 位相と振幅がほぼ一致している. このことから, 空気圧で浮上する平板は上下方向に並進振動していることがわかる. 支持構造については, シャ フトとリニアベアリングによって並進移動以外の動きを拘束しているため (図 3 参照), こちらも上下方向に並進 振動している.

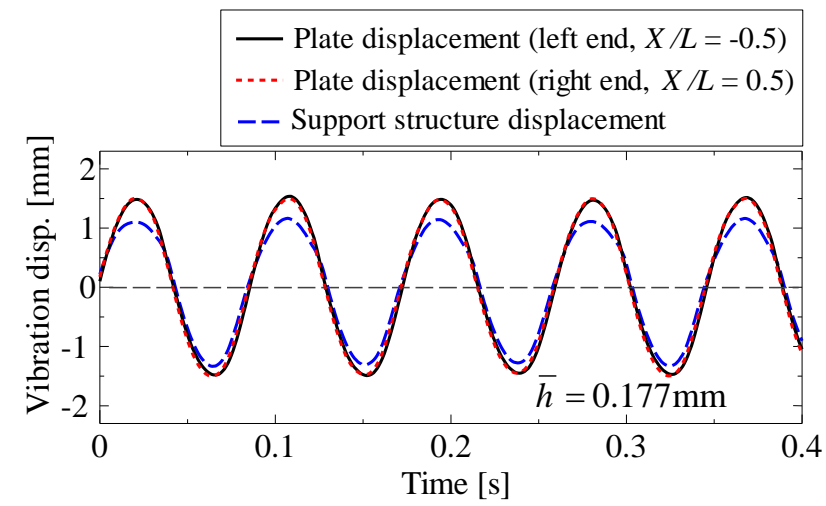

(a) In-phase mode in the case of $M=40.4 \mathrm{~kg}$

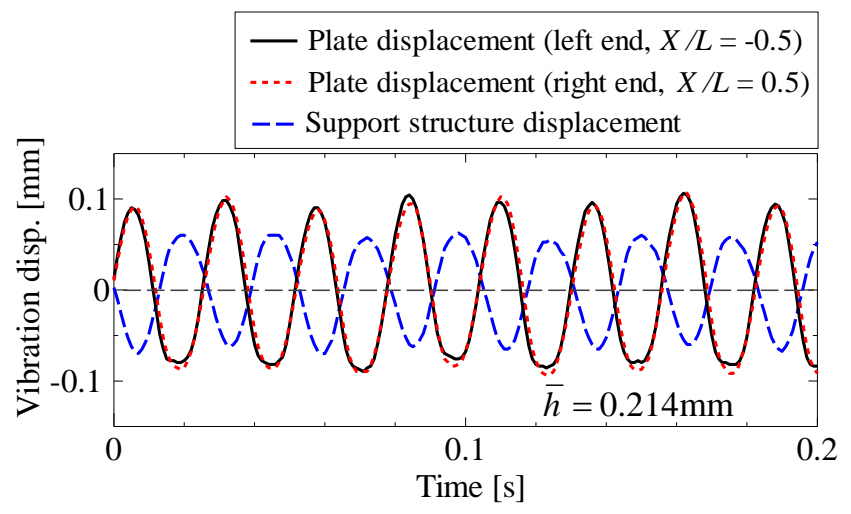

(b) Anti-phase mode in the case of $M=11.6 \mathrm{~kg}$

Fig. 7 Time histories of the vibration displacement of the plate and the support structure for $Q_{s}=0.30 \mathrm{~m}^{3} / \mathrm{min}$, $k_{s}=50.2 \times 10^{4} \mathrm{~N} / \mathrm{m}$. The self-excited vibration of in-phase mode and anti-phase mode occurs in the plate and the support structure.

\section{2 根軌跡と振動モード}

困 8 に，空気流量を変化させた場合の根軌跡の計算結果を示す。また，図 9 に，流量を变化させた場合の，支 持構造の振動変位に対する平板振動変位の位相差を示す. これらの図は，平板質量 $M=40.4 \mathrm{~kg}$, バネ定数 $k_{s}=50.2 \times 10^{4} \mathrm{~N} / \mathrm{m}$ の場合の結果である. 図 9 に示した位相差は, 平板振動変位が支持構造の振動変位に対して位 相進みである場合は正の位相差を, 位相遅れである場合は負の位相差を示す。また，図 9 の赤の実線と青の破線 で示した結果は，それぞれ図 8 に示した赤の実線で示した特性根と，青の破線で示した特性根に対応している.

図 8 より, 空気流量が小さい場合は，特性根の実部は負であり系は安定であるが，空気流量が増加すると，赤 の実線と青の破線で示した 2 つ特性根の実部が正になり，自励振動が発生することがわかる．図 $9 よ り ，$ 赤の 実線で示した特性根が不安定化することで発生する自励振動は，平板と支持構造がほぼ同位相で振動する同位相 モードの自励振動であることがわかる，一方，青の破線で示した特性根が不安定化することで発生する自励振動 は, 平板と支持構造がほぼ逆位相で振動する逆位相モードの自励振動である. この解析結果と上述の実験結果 (図 7 参照）より，支持構造が弾性支持された系（支持構造が上下方向に自由度を有する系）では，同位相モ一ドと 逆位相モードの自励振動が発生することがわかる。しかしながら，自励振動が発生する臨界流量は，同位相モー ドと逆位相モードで異なる。同位相モードと逆位相モードの自励振動が発生する条件，また支持構造の弾性が自 励振動の発生条件に及ぼす影響については，後述の $4 \cdot 3$ 節で示す. 


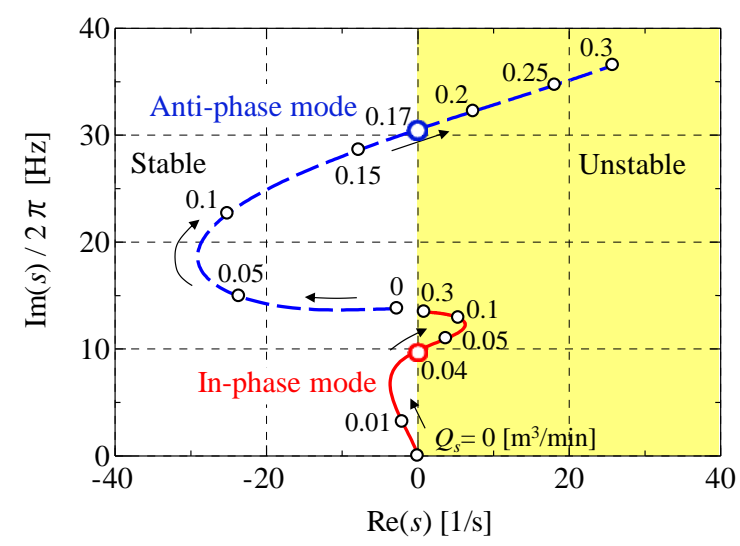

Fig. 8 Root locus with increasing air flow rate for $k_{s}=50.2 \times 10^{4} \mathrm{~N} / \mathrm{m}, M=40.4 \mathrm{~kg}$. As air flow rate increases, the real part of the characteristic roots of red line and blue line become positive and the system becomes unstable.

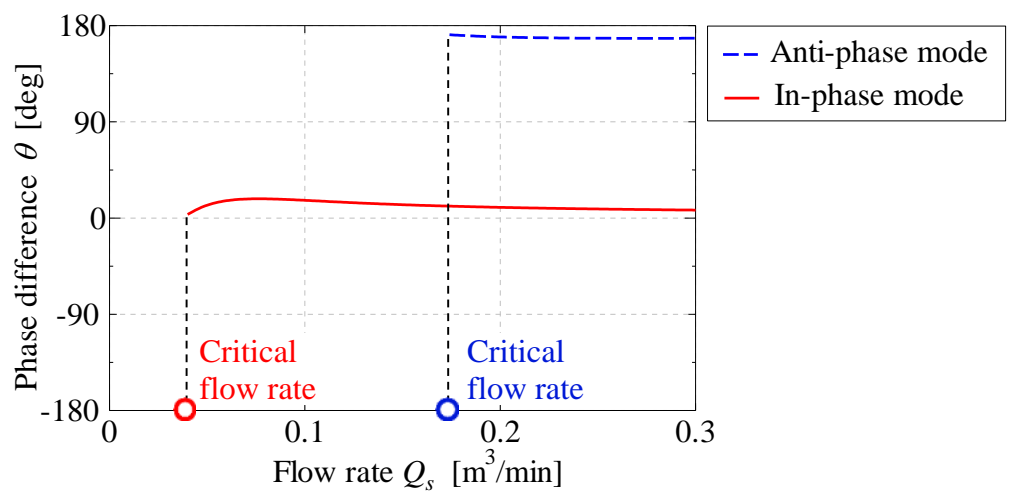

Fig. 9 Phase difference of the plate displacement $\Delta Z_{p}$ against the support structure displacement $\Delta Z_{s}$ with increasing air flow rate for $k_{s}=50.2 \times 10^{4} \mathrm{~N} / \mathrm{m}, M=40.4 \mathrm{~kg}$. The mode of red line is in-phase mode in which the plate and support structure vibrate in almost same phase. On the other hand, the mode of blue line is anti-phase mode in which the plate and support structure vibrate in almost opposite phase.

\section{$4 \cdot 3$ 自励振動発生条件}

図 10(a) (c) に, 平板質量 $M$ と空気流量 $Q_{s}$ を変化させた場合の自励振動発生条件を示寸. 図 $10(\mathrm{a})$ は, 支持構造 のバネ定数が小さい場合 $\left(k_{s}=10.5 \times 10^{4} \mathrm{~N} / \mathrm{m}\right)$, 図 10(b)は, 支持構造のバネ定数が大きい場合 $\left(k_{s}=50.2 \times 10^{4} \mathrm{~N} / \mathrm{m}\right)$ の結果である. さらに, 図 10(c)には, 支持構造を固定し $\left(k_{s}=\infty\right)$, 空気圧で浮上寸る平板のみが上下方向に振 動する場合の結果を示す.また，図 11 に，図 10 の結果を式（36）に示した無次元数を用いて無次元化した自励 振動発生条件を示す．図中に示した曲線は解析結果を示し，赤の曲線で囲まれた領域は同位相モード，青の曲線 で囲まれた領域は逆位相モード, 緑の曲線で囲まれた領域は支持構造を固定した場合の自励振動発生領域を示し ている.また，×との，〕，○は実験結果を示しており，×が安定状態，のが同位相モード，○は逆位相モード， ○は平板のみが振動する自励振動が発生したことを示している.

なお，図 10(b)と図 11(b)では，赤の曲線で囲まれた同位相モードの自励振動発生領域と青の曲線で囲まれた逆 位相モードの自励振動発生領域が重なる領域がある。この領域については，振動が成長し安定なリミットサイク ルに入る過程で，どちらかの振動モードが卓越するが，本研究の動的安定性解析では振動に関する非定常項は小 さいとした線形解析モデルを用いているため，その過程を追うことができない．このため，同位相と逆位相モー ドの自励振動発生領域が重なる領域の境界については, 参考として解析結果を点線にて示している. 
Takeda, Ozawa and Watanabe, Transactions of the JSME (in Japanese), Vol.85, No.872 (2019)

図 10 と図 11 より，支持構造のバネ定数が小さい場合，つまり支持構造を柔軟に支持した場合は，逆位相モー ドの自励振動発生領域が広くなることがわかる。一方，支持構造のバネ定数が大きい場合，つまり支持構造を硬 く支持した場合は，同位相モードの自励振動発生領域が広くなる．また，支持構造を固定した場合（空気圧で浮 上する平板のみが振動する場合）は，支持構造を硬く支持した場合と比較して自励振動発生領域に大きな変化は ないことがわかる.

これらの結果では, 解析結果と実験結果は定性的には一致しているものの, 自励振動が発生する臨界流量の下 限に定量的な差異が見られる。 これは，平板と支持構造に生じる曲げ変形の影響が主な原因であると思われる. 平板には，平板上部に載せた重り（図 3 参照）と，平板下部の寸き間に供給した空気の圧力により曲げ変形が生 じる. また，支持構造も同様に，供給した空気の圧力により曲げ変形が生じる. 本研究の解析モデルでは, 支持 構造の弾性を考慮するためにバネを付加したが，支持構造と平板に生じる曲げ変形（弾性変形）の影響は考慮し ていないため, 解析結果と実験結果に差異が生じたと考えられる.

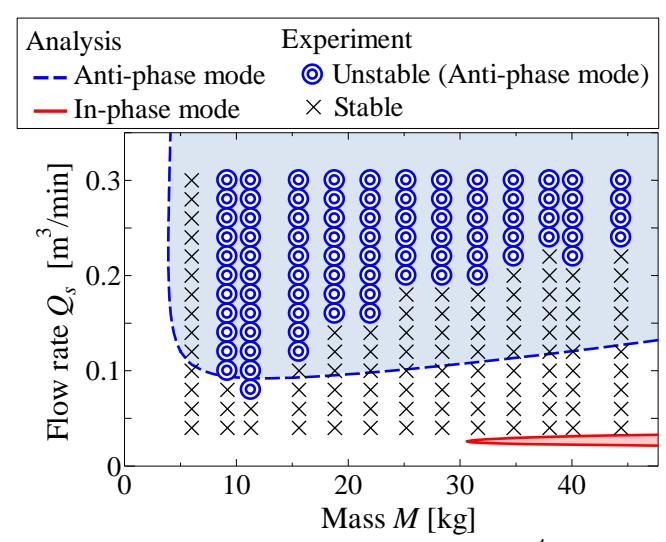

(a) In the case of $k_{s}=10.5 \times 10^{4} \mathrm{~N} / \mathrm{m}$

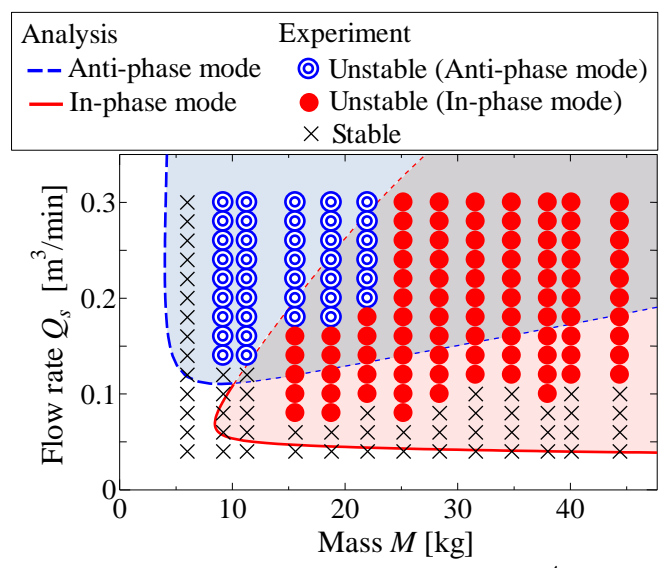

(b) In the case of $k_{s}=50.2 \times 10^{4} \mathrm{~N} / \mathrm{m}$

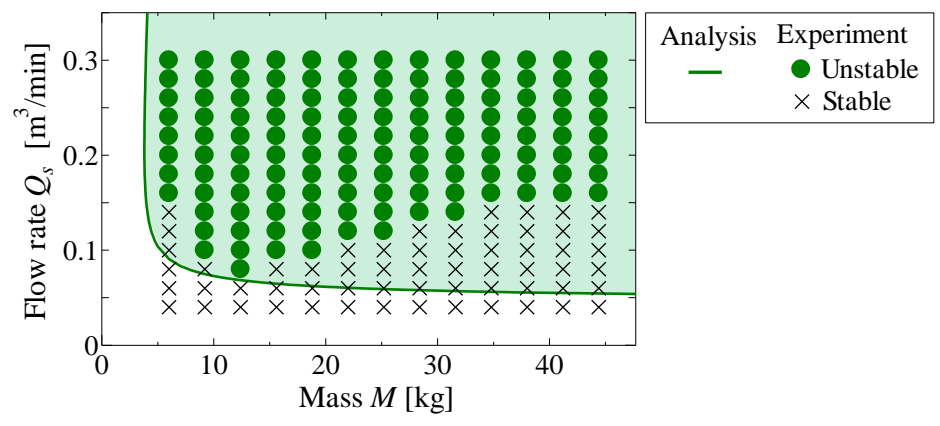

(c) In the case of fixed support structure $\left(k_{s}=\infty\right)$

Fig. 10 Critical flow rate $Q_{s-c r}$ as a function of plate mass $M$ for various spring constant $k_{s}$. When the elasticity of the support structure is small, the anti-phase mode vibration occurs in a wide area. On the other hand, when the elasticity of the support structure is large, the anti-phase mode vibration and the in-phase mode vibration occur. In the case which the support structure is fixed, only the plate vibrates to vertical direction. 


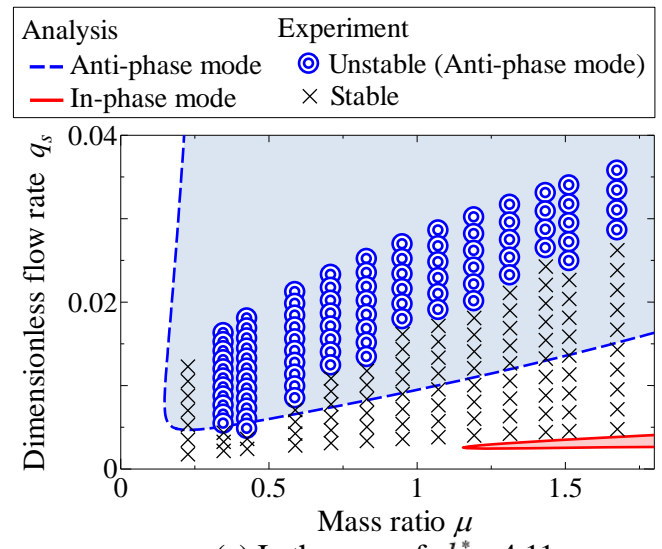

(a) In the case of $k_{s}^{*}=4.11$

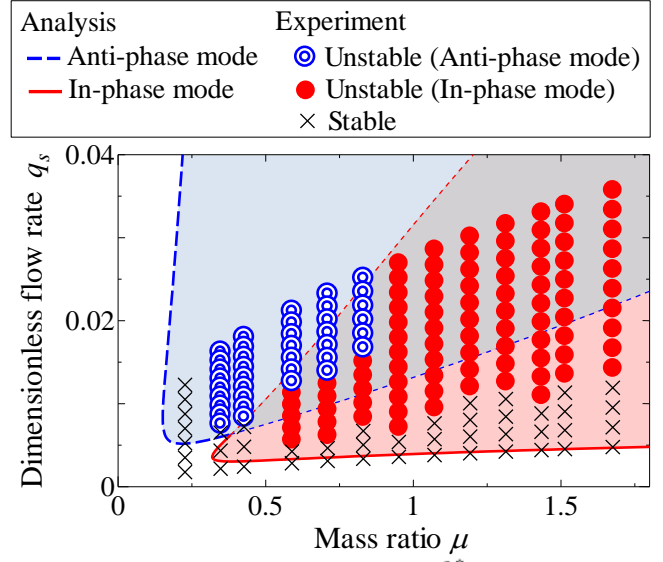

(b) In the case of $k_{s}^{*}=19.6$

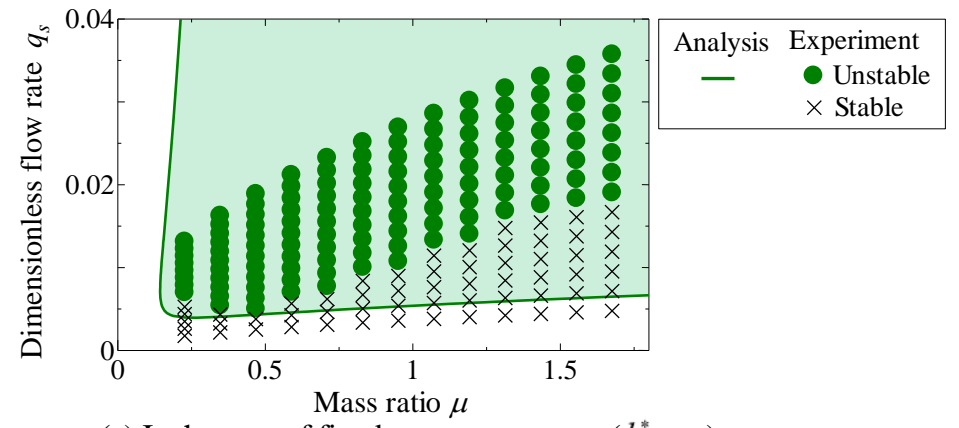

(c) In the case of fixed support structure $\left(k_{s}^{*}=\infty\right)$

Fig. 11 Critical dimensionless flow rate $q_{s-c r}$ as a function of mass ratio $\mu$ for various dimensionless spring constant $k_{s}^{*}$. When the mass ratio is small, the system is stable. On the other hand, as the mass ratio becomes large, the self-excited vibration occurs regardless of the value of the dimensionless spring constant.

さらに，支持構造の減衰要素が系の動的安定性に及ぼす影響を調べるために，図 12 に支持構造の減衰比 $\zeta$ を 変化させた場合の自励振動発生領域を示す. 図の横軸は支持構造に対する平板の質量比 $\mu$, 縦軸は無次元流量 $q_{s}$ を表し，ここでは無次元バネ定数 $k_{s}^{*}=19.6$ において，支持構造の減衰比 $\zeta を 0.01,0.05,0.1$ と 3 通りに変化させ た場合の解析結果を示す．図より，支持構造の減衰比が小さい場合では，赤の曲線で示した同位相モードの自励 振動発生領域は広くなることがわかる．また，青の曲線で示した逆位相モードの自励振動発生領域についても， 減衰比が小さい場合では，その領域は広くなるが，同位相モードの自励振動発生領域と比べて変化は小さい.

この結果から，支持構造の弾性に加えて，支持構造の減衰要素も系の動的安定性に重要な因子であることがわ かる.

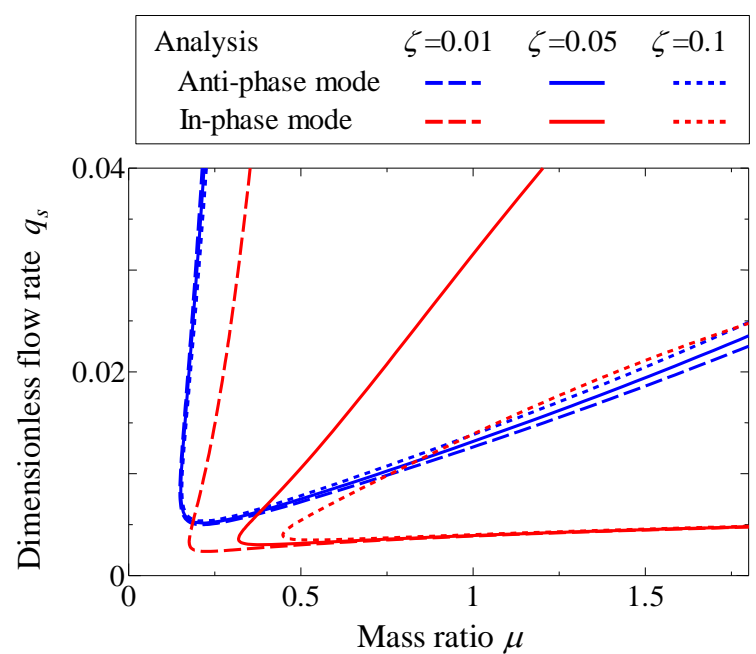

Fig. 12 Critical dimensionless flow rate $q_{s-c r}$ as a function of mass ratio $\mu$ for various damping ration of the support structure $\zeta$ for $k_{s}^{*}=19.6$. When the damping ratio is small, the self-excited vibration occurs in a wide area. Particularly, the region where the in-phase mode vibration occurs becomes wider. On the other hand, the change of the region where the anti-phase mode vibration occurs is small. 


\section{$4 \cdot 4$ 流体カの仕事分布と励振メカニズムの考察}

図 13(a) (c) に，解析と実験で得られた流体力の仕事分布 $E_{\text {local }} \quad((\mathrm{a} 1) \sim(\mathrm{c} 1)), \quad Y$ 軸中央断面 $(Y / D=0)$ におけ る流体力の仕事分布 $E_{\text {local }}((\mathrm{a} 2) \sim(\mathrm{c} 2))$, 流体力の（支持構造に対する平板の）相対振動変位に対する位相差（(a3) 〜(c3)）を示す．図 13(a)は同位相モードの結果，図 13(b)は逆位相モードの結果である.また，比較のために，図 13(c) に支持構造を固定 $\left(k_{s}^{*}=\infty\right)$ した場合の結果, つまり平板のみが振動する場合の結果を示す. 設定した空気 流量は，解析では臨界流量 $\left(Q_{s}=Q_{s-c r}\right)$ とした。一方，実験では，自励振動が発生する流量（同位相モードは $Q_{s}=0.16 \mathrm{~m}^{3} / \mathrm{min}$, 逆位相モードと支持構造を固定した場合では $\left.Q_{s}=0.25 \mathrm{~m}^{3} / \mathrm{min}\right)$ で測定を行った. 流体力に よる仕事は，それぞれの最大值で正規化して（最大值を 1 で）表示している.ここで，赤色は流体力による仕事 が正の領域を, 青色はその仕事が負の領域を表している. また, 流体力（圧力変動）の相対振動変位に対する位 相差は, 圧力变動が振動変位に対して位相進みである場合は正の位相差を，位相遅れである場合は負の位相差を 示す.

ここで, 平板と支持構造の振動は, 前述の図 7 に示した結果より, 並進振動していることがわかる. 本研究で 対象とした流路中央に設けた 1 本のスリットから空気を供給する系では，並進振動する場合，すき間内の圧力変 動はスリットの位置を基準として, ほぼ対称な分布を有することが示されている(武田, 渡辺, 2016).このため, 実験結果は, $X / L=0 \sim 0.5, Y / D=0 \sim 0.5$ の範囲で圧力変動を計測することで得られた結果を, 対称性を利用 して $X / L=-0.5 \sim 0.5, Y / D=-0.5 \sim 0.5$ の範囲で表示している.

図 13(a1), (a2)と(b1), (b2)より, 振動モードによらずスリット直上およびその付近で流体力による仕事が正であ り，エネルギが流入していることがわかる，つまり，スリット直上およびその付近の領域で流体力（圧力変動） が，平板と支持構造の振動に対して正の仕事をするために自励振動が発生する. また，図 13(c1), (c2)より，支持 構造を固定した場合（空気圧で浮上する平板のみが振動する場合）でも同様に，スリット直上およびその付近で 流体力による仕事が正であることがわかる，つまり，支持構造の弾性によらず，自励振動を励起する励振流体力 は，スリット直上およびその付近で作用する.

ここで示した流体力の仕事分布の解析結果と実験結果について, エネルギ流入と散逸の傾向は一致しているが, 仕事分布には差が見られる．これは，前述の 4 ・3 節で考察した，支持構造と平板に生じる曲げ変形 (弾性変形) が主な原因と思われる，解析では曲げ変形の影響は考慮していないが，実験では曲げ変形に起因して平板と支持 構造の間の寸き間幅が変化する. そして，このすき間幅の変化に起因して，すき間内の流体力の大きさが変化し たため，流体力の仕事分布に差が生じたと考えられる.

図 13(a3)，(b3)より，同位相モードと逆位相モード，どちらの振動モードにおいても，スリット直上およびその 付近での圧力変動が, 支持構造に対寸る平板の相対振動変位に対して位相進みであり, この領域における圧力変 動が自励振動を励起する. この結果は, 図 13(c3)に示した, 空気圧で浮上する平板のみが振動する 1 自由度系の 結果と同様の傾向を示している。このことから, 空気圧で浮上する平板と支持構造が連成して振動する系の励振 機構は, 空気圧で浮上寸る平板のみが振動する 1 自由度系の励振機構と同様であることがわかる. さらに, 前報 （武田, 渡辺, 2016）に示した，系の動的安定性を支配する位相特性を調べた結果より，自励振動を励起するスリ ット直上およびその付近の圧力変動の位相進みは, チャンバ内の空気の圧縮性に起因して発生することが明らか にされている.つまり, 空気圧で浮上する平板と支持構造が連成して振動する系でも基本的な励振メカニズムは 同様であり，チャンバ内の空気の圧縮性に起因して，平板と支持構造に自励振動が発生する. 


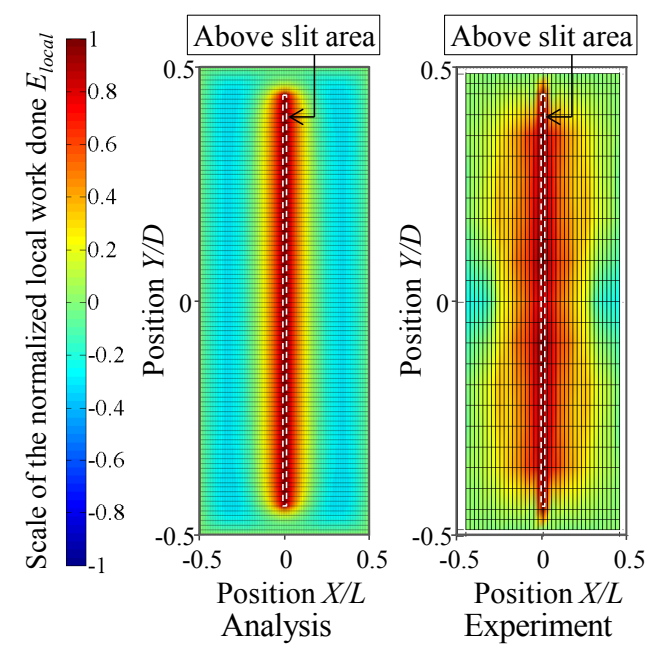

(a1) Normalized local work done $E_{\text {local }}$

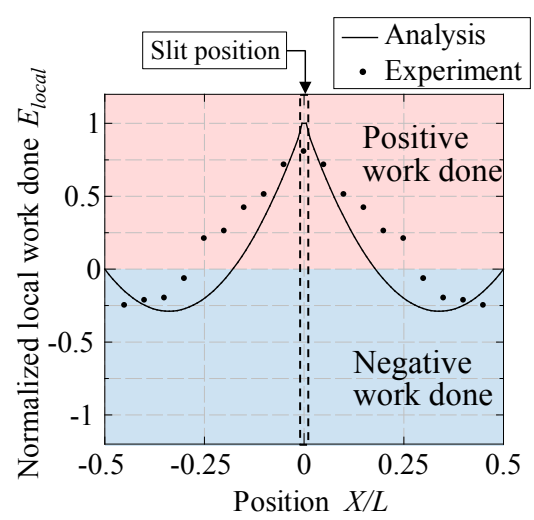

(a2) Normalized local work done $E_{\text {local }}$ by the unsteady fluid force $(Y / D=0)$

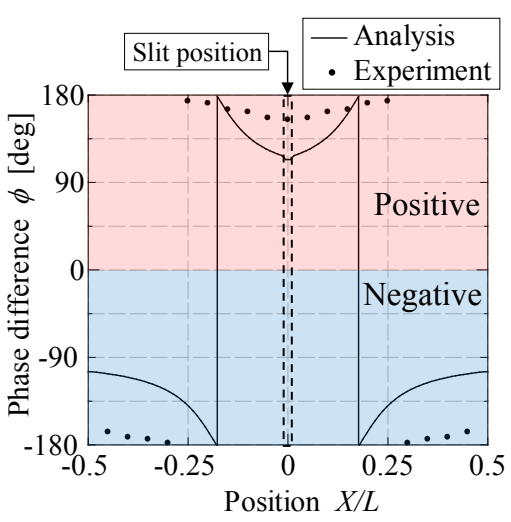

(a3) Phase difference of the fluid pressure $\Delta P_{g}$ against the relative displacement $\Delta h(Y / D=0)$ by the unsteady fluid force

(a) In the case of in-phase mode $\left(k_{s}^{*}=19.6, \mu=0.72\right)$

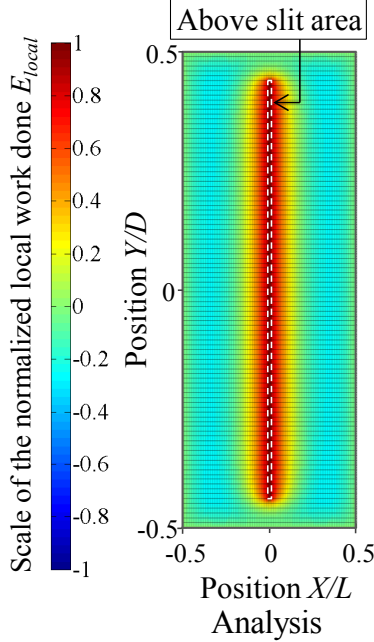

Analysis

(b1) Normalized local work done $E_{\text {local }}$

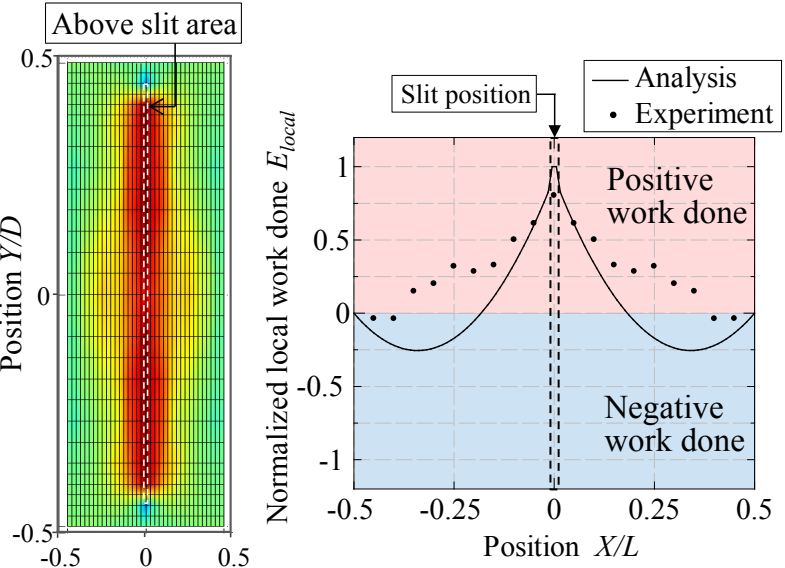

(b2) Normalized local work done $E_{\text {local }}$ by the unsteady fluid force $(Y / D=0)$

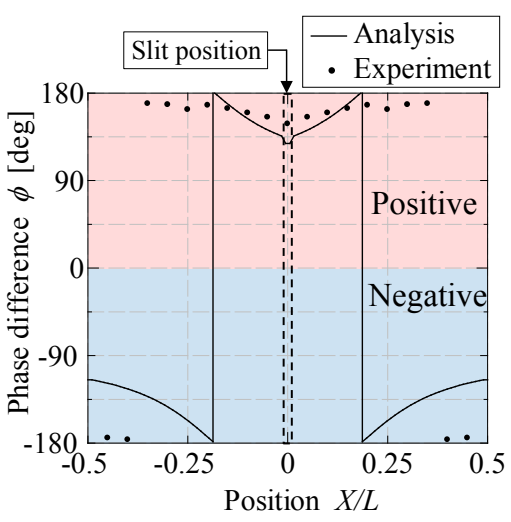

(b3) Phase difference of the fluid pressure $\Delta P_{g}$ against the relative displacement $\Delta h(Y / D=0)$

(b) In the case of anti-phase mode $\left(k_{s}^{*}=19.6, \mu=0.36\right)$

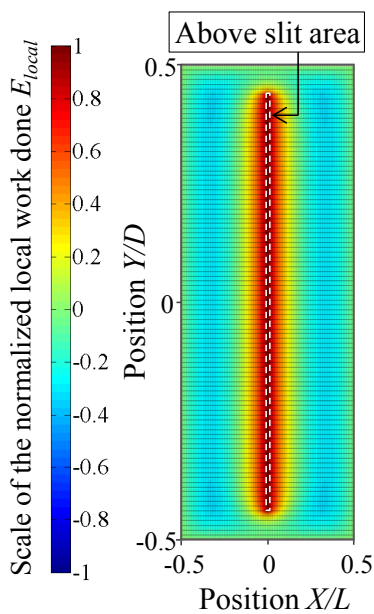

Analysis

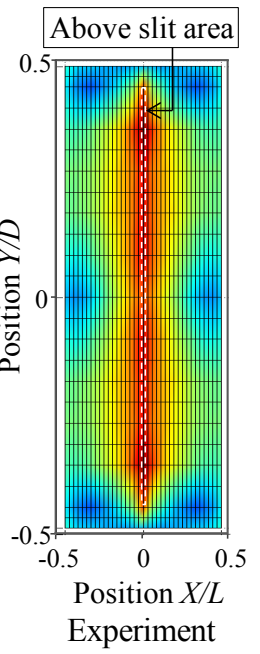

Experiment

(c1) Normalized local work done $E_{\text {local }}$ by the unsteady fluid force

(c) In the case of fixed support structure $\left(k_{s}^{*}=\infty, \mu=0.44\right)$

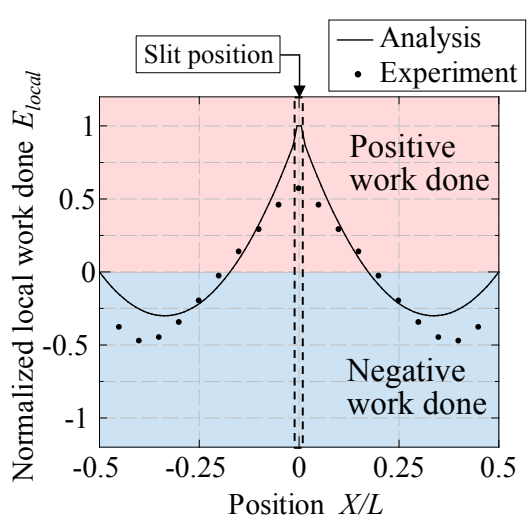

(c2) Normalized local work done $E_{\text {local }}$ by the unsteady fluid force $(Y / D=0)$

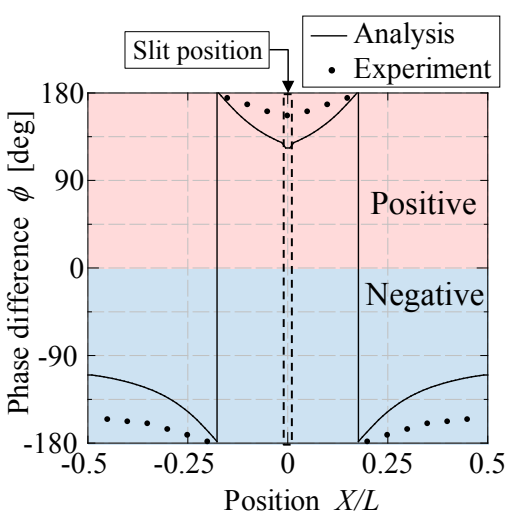

(c3) Phase difference of the fluid pressure $\Delta P_{g}$ against the relative displacement $\Delta h(Y / D=0)$

Fig. 13 Normalized local work done $E_{\text {local }}$ by the unsteady fluid force and phase difference of fluid pressure $\Delta P_{g}$ against relative vibration displacement $\Delta h$. Regardless the vibration mode, the local work around the slit is positive, in particular, above the slit where it is the largest. The phase lead of the pressure fluctuation around the slit contributes to the occurrence of the positive work. 


\section{5. まとめ}

本研究では，空気圧で浮上する平板と支持構造を対象に，空気の圧縮性と流体慣性を考慮した解析モデルを構 築し, 空気圧で浮上する平板と支持構造に発生する自励振動の特性と発生条件を調べた。また，実験を行い，解 析と実験結果を比較することで，支持構造の弾性が自励振動の特性と発生条件に及ぼす影響を明らかにした．特 に本研究では, 空気圧で浮上する平板と支持構造の安定性を支配する無次元数である, 無次元流量, 質量比, 無 次元バネ定数を定義し, 自励振動が発生する条件を整理した. さらに, 平板と支持構造の表面に作用する流体力 の仕事分布を調べることで, 自励振動発生時のエネルギ収支を明らかにし, 励振メカニズムを考察した. 得られ た主な結果を以下に示す.

（1）支持構造が弾性支持された系（支持構造が上下方向に自由度を有する系）では，空気流量が増加すると， 平板と支持構造が同位相で振動するモード(同位相モード) と, 逆位相で振動するモード(逆位相モード), 2 つのタイプの自励振動が発生する.

（2）支持構造のバネ定数が小さい場合，つまり支持構造を柔軟に支持した場合は，逆位相モードの自励振動発 生領域が広くなる，一方，支持構造のバネ定数が大きい場合，つまり支持構造を硬く支持した場合は，同 位相モードの自励振動発生領域が広くなる。

（3）支持構造を固定した場合（空気圧で浮上する平板のみが振動する場合）は，支持構造を硬く支持した場合 と比較して自励振動発生領域に大きな変化はない.

(4) 同位相モードと逆位相モード，どちらの振動モードにおいても，スリット直上およびその付近での圧力変 動が，支持構造に対する平板の相対振動変位に対して位相進みであり，この領域における圧力変動が自励 振動を励起する.

（5）前報 (武田, 渡辺, 2016）より, 自励振動を励起するスリット直上およびその付近の圧力変動の位相進みは, チャンバ内の空気の圧縮性に起因して発生することが示されている.つまり, 空気圧で浮上寸る平板と支 持構造が連成して振動する系でも基本的な励振メカニズムは同様であり，チャンバ内の空気の圧縮性に起 因して自励振動が発生する.

\section{主な記号}

$\begin{array}{lll}A_{d} & : & \text { 流路の格子面積 } \\ A_{g} & : & \text { すき間入口の面積 } \\ A_{s} & : & \text { スリットの面積 } \\ B & : & \text { スリットの長さ } \\ C_{d g} & : & \text { すき間入口の流量係数 } \\ C_{d s} & : & \text { スリット部の流量係数 } \\ c & : & \text { 減衰係数 } \\ D & : & \text { 平板の長さ } \\ D_{s} & : & \text { 支持構造表面の長さ } \\ d & : & \text { スリットの幅 } \\ E_{l o c a l} & : & \text { 局所的な流体力による仕事 } \\ F & : & \text { 平板と支持構造に作用する流体力 } \\ g & : & \text { 重力加速度 } \\ h & : & \text { 支持構造に対する平板の相対変位 } \\ j & : \text { 節点番号 } \\ K_{e} & : & \text { 空気の体積弾性係数 } \\ K_{e 0} & : & \text { 大気圧中の空気の体積弾性係数 } \\ k & : & \text { 節点番号 } \\ k_{s} & : & \text { バネ定数 }\end{array}$

\begin{tabular}{|c|c|c|}
\hline$k_{s}^{*}$ & : & 無次元バネ定数 \\
\hline$L$ & $:$ & 平板の幅 \\
\hline$L_{s}$ & $:$ & 支持構造表面の幅 \\
\hline$\ell_{x}$ & : & 無次元化した $X$ 方向の流路格子長さ \\
\hline$\ell_{y}$ & $:$ & 無次元化した $Y$ 方向の流路格子長さ \\
\hline$M$ & $:$ & 平板と積載物の合計質量 \\
\hline$M_{s}$ & $:$ & 支持構造の質量 \\
\hline$N_{X}$ & $:$ & $X$ 方向の流路分割数 \\
\hline$N_{Y}$ & $:$ & $Y$ 方向の流路分割数 \\
\hline$P$ & $:$ & チャンバ内の圧力 \\
\hline$P_{a}$ & $:$ & 大気圧 \\
\hline$P_{g}$ & $:$ & すき間内の圧力 \\
\hline$P_{g 0}$ & $:$ & すき間入口の圧力 \\
\hline$P_{s}$ & $:$ & スリット直上の圧力 \\
\hline$Q$ & $:$ & スリットを通過する空気流量 \\
\hline$Q_{X}$ & $:$ & $\begin{array}{l}\text { すき間内の } X \text { 方向に流れる空気の単位 } \\
\text { 幅あたりの流量 }\end{array}$ \\
\hline$Q_{Y}$ & $:$ & $\begin{array}{l}\text { 寸き間内の } Y \text { 方向に流れる空気の単位 } \\
\text { 幅あたりの流量 }\end{array}$ \\
\hline
\end{tabular}




\begin{tabular}{|c|c|}
\hline$Q_{s}$ & チャンバに供給される空気流量 \\
\hline$q_{s}$ & 無次元流量 \\
\hline$s$ & ラプラス変数 \\
\hline$T_{s}$ & 代表時間 \\
\hline$t$ & 時間 \\
\hline V & チャンバ内部の体積 \\
\hline$X$ & $X$ 方向 \\
\hline$x$ & 無次元化した $X$ 方向座標 \\
\hline$Y$ & $Y$ 方向 \\
\hline$y$ & 無次元化した $Y$ 方向座標 \\
\hline$Z$ & $Z$ 方向 \\
\hline$Z_{p}$ & 平板の変位 \\
\hline$Z_{s}$ & 支持構造の変位 \\
\hline & 減衰比 \\
\hline
\end{tabular}

$\begin{array}{lll}\theta & : & \begin{array}{l}\text { 支持構造の振動変位に対する } \\ \text { 平板振動変位の位相差 }\end{array} \\ \mu & : & \text { 支持構造に対する平板の質量比 } \\ v & : & \text { 空気の動粘性係数 } \\ \rho & : & \text { すき間内の空気密度 } \\ \rho_{a} & : & \text { 大気圧下における空気密度 } \\ \rho_{s} & : & \text { スリット部の空気密度 } \\ \phi & : & \text { 相対振動変位に対する流体力の位相差 }\end{array}$

\section{文献}

稲田文夫, 葉山眞治, 寸きま流励起振動に関する研究 (第 1 報, 一次元テーパすきまの壁面に作用する流体力の評 価）, 日本機械学会論文集 C 編, Vol. 53, No. 488 (1987),pp.933-939.

石原国彦, 空気浮上式コンベアにおいて発生する異常振動について(現象の理解), 日本機械学会論文集 C 編, Vol. 73, No. 729 (2007), pp.1279-1284.

Ishihara, K., On abnormal vibration generated in flow dynamic conveyer, Journal of System Design and Dynamics, Vol. 2, No. 2 (2008), pp.550-560.

Ishihara, K. and Eto, D., Study on generation mechanism of abnormal vibration of flow dynamic conveyer, Journal of System Design and Dynamics, Vol. 5, No. 4 (2011), pp.589-602.

Li, D.-W., Kaneko, S. and Hayama, S., A study on annular leakage-flow-induced vibrations, Journal of Fluids and Structures, Vol.16 (2002), pp.909-930.

大森直陸, 小林正生, 空気浮上した柔軟ベルトの安定性に関する研究, 日本機械学会 Dynamics and Design Conference 2000 CD-ROM 講演論文集, No.342 (2000).

大森直陸, 小林正生, 空気浮上した柔軟ベルトの安定性に関する研究（第2 報 荷を積載した場合）, 日本機械学 会 Dynamics and Design Conference 2001 CD-ROM 講演論文集, No.609 (2001).

下川靖夫, 大久保雅章, 神山新一, 流体クッションによる薄鋼板の非接触支持に関寸る研究 (サイドプレートによ る浮上力および復元力の向上），日本機械学会論文集 B 編, Vol. 60, No. 575 (1994), pp.2425-2430.

下川靖夫, 神山新一, 流体クッションによる薄鋼板の非接触支持に関する研究 (浮上搬送用サイドプレートの最適 化による消費流量軽減策）, 日本機械学会論文集 B 編, Vol. 62, No. 600 (1996), pp.3082-3087.

武田真和, 渡辺昌宏, 空気圧で浮上寸る平板の動的安定性と励振メカニズムの考察, 日本機械学会論文集, Vol. 82, No. 838 (2016), DOI:10.1299/transjsme.16-00015.

武田真和, 渡辺昌宏, 空気圧で浮上寸る平板に発生する自励振動の特性と発生条件 (チャンバ体積とスリット幅が 自励振動の発生条件に及ぼす影響) ，日本機械学会論文集, Vol. 84, No. 858 (2018), DOI:10.1299/transjsme.17-00415.

\section{References}

Inada, F. and Hayama, S., A study on leakage-flow-induced vibrations (1st report, Fluid-dynamic forces acting on the walls of a one-dimensional, narrow, tapered passage), Transactions of the Japan Society of Mechanical Engineers, Series C, Vol. 53, No. 488 (1987), pp.933-939 (in Japanese).

Ishihara, K., On abnormal vibration generated in flow dynamic conveyer (Understanding of phenomenon), Transactions of the Japan Society of Mechanical Engineers, Series C, Vol. 73, No. 729 (2007), pp. 1279-1284 (in Japanese).

Ishihara, K., On Abnormal vibration generated in flow dynamic conveyer, Journal of System Design and Dynamics, Vol. 2, No. 2 (2008), pp.550-560.

Ishihara, K. and Eto, D., Study on generation mechanism of abnormal vibration of flow dynamic conveyer, Journal of System Design and Dynamics, Vol. 5, No. 4 (2011), pp.589-602. 
Li, D.-W., Kaneko, S. and Hayama, S., A study on annular leakage-flow-induced vibrations, Journal of Fluids and Structures, Vol.16 (2002), pp.909-930.

Oomori, N. and Kobayashi, M., Stability analysis of flexible belt floating on air flow, Transactions of the Japan Society of Mechanical Engineers Dynamics and Design Conference 2000 , No.342 (2000) (in Japanese).

Oomori, N. and Kobayashi, M., Stability analysis of flexible belt floating on air flow (2nd report), Transactions of the Japan Society of Mechanical Engineers Dynamics and Design Conference 2001 , No.609 (2001) (in Japanese).

Shimokawa, Y., Okubo, M. and Kamiyama, S., Basic study of non-contacting support of thin plate by fluid cushion force (Effect of side plates on supporting characteristics), Transactions of the Japan Society of Mechanical Engineers, Series B, Vol. 60, No. 575 (1994), pp. 2425-2430 (in Japanese).

Shimokawa, Y. and Kamiyama, S., Non contacting support of strip by fluid cushion force (Reducing flow rate for floating strip by optimizing shape of side plates), Transactions of the Japan Society of Mechanical Engineers, Series B, Vol. 62, No. 600 (1996), pp. 3082-3087 (in Japanese).

Takeda, M. and Watanabe, M., Dynamic stability and exciting mechanism of a plate supported by air pressure, Transactions of the JSME (in Japanese), Vol. 82, No. 838 (2016), DOI:10.1299/transjsme.16-00015.

Takeda, M. and Watanabe, M., Characteristics of a self-excited vibration of a plate supported by air pressure (Influence of chamber volume and slit width on occurrence conditions of the self-excited vibration), Transactions of the JSME (in Japanese), Vol. 84, No. 858 (2018), DOI:10.1299/transjsme.17-00415. 